\title{
Geoffrey of Monmouth's Classical and Biblical Inheritance
}

\author{
Paul Russell
}

The "very old book in the British tongue" brought to Geoffrey by Walter has always been the natural starting point for any discussion of Geoffrey and his sources for the De gestis Britonum. ${ }^{1}$ But the sentence which follows mention of the book (apart from its reference to translation (transferre)) has attracted relatively somewhat less attention:

Though I have never gathered showy words from the gardens of others, I was persuaded by [Walter's] request to translate the book into Latin in a rustic style [lit. stilus], reliant on my own reed pipe. ${ }^{2}$

But this is arguably even more revealing of his sources than the preceding sentence with its much discussed "very old book" and references to the works of Gildas and Bede. The crucial phrase, which could be taken as Geoffrey's nod toward the modesty topos, is agresti tamen stilo propriisque calamis, "in a rustic

$1 \quad D G B$, Prologus 2.9-10: “... quendam Britannici sermonis librum uestustissimum ...” Translations of the $D G B$ are normally Wright's unless it was felt necessary to vary it; for other texts, translations are my own unless otherwise indicated. To a large extent the following discussion focuses in the $D G B$, which provides many more complex examples to consider, but some cases where Geoffrey draws on classical sources in the $V M$ are also discussed. His debt to biblical sources in the latter is less easy to pin down; for a discussion of some of the theological aspects of the $V M$, see Barry Lewis's chapter in this volume (pp. 420-23). I am grateful to Ben Guy for reading a draft of this chapter and for the comments of the anonymous referees, and also to the editors for their careful guidance and help.

2 DGB, Prologus 2.12-15: “... Rogatu itaque illius ductus, tametsi infra alienos ortulos falerata uerba non collegerim, agresti tamen stilo propriisque calamis contentus codicem illum in Latinum sermonem transferre curaui ..." Wright, and others (Geoffrey of Monmouth, De gestis Britonum, trans. L. Thorpe, Geoffrey of Monmouth: The History of the Kings of Britain, London, 1966, p. 51; Geoffrey of Monmouth, De gestis Britonum, trans. M.A. Faletra, The History of the Kings of Britain, Geoffrey of Monmouth, Peterborough, Ontario, 2007, p. 41), render stilo as "style" but it may be intended more precisely as stilus, "pen, stylus". 
style, reliant on my own reed pipe"; on the face of it, he seems to be taking refuge in the rusticity of his Latin as an excuse for a lack of polish. But there is something else going on here. In the longer prologue containing a joint dedication to Robert of Gloucester and Waleran of Meulan, which is preserved in ten manuscripts, the veil is pulled back a little further: ${ }^{3}$

... so that I may rest beneath the shade of your spreading branches and my muse can play her melody on my rustic pipe, safe from envious critics. ${ }^{4}$

Under the protection of Robert and Waleran, Geoffrey has had the time and the space to listen to his Muse. But at this point the allusion to (and the partial quotation of) Virgil's first Eclogue is unmistakable and was clearly intended for what it was (the relevant phrases are italicized):

\section{Meliboeus: You, Tityrus, lie shaded by the spreading branches of a beech} and woo the woodland muse with your slender reed;

but we are leaving the lands of our country and its pleasant fields. We in exile from our country; you, Tityrus, at ease in the shade teaching the woods re-echo 'Fair Amaryllis'.

Tityrus: O Meliboeus, a god has brought about this peace for us;

For he shall always be a god to me, and often shall a tender lamb from our folds stain his altar.

He has permitted my cattle to roam, as you can see, and me to play what I like upon my rustic pipes. ${ }^{5}$

3 On the Waleran prologue, see $D G B$, pp. ix-x and xix; cf. Geoffrey of Monmouth, De gestis Britonum, ed. A. Griscom, The Historia Regum Britanniae of Geoffrey of Monmouth with Contributions to the Study of its Place in early British History with a Literal Translation of the Welsh Manuscript No. LXI of Jesus College Oxford, London, 1929, pp. 49-5o.

$4 D G B$, Prologus 4.8-10 (n. 23.8-10): “... ut sub tegmine tam patulae arboris recubans calamum musae meae coram inuidis atque improbis tuto modulamine resonare queam"; improbis is understood here by Wright as "critics", but others take it to reflect a more general hostility: "envious and malicious enemies" (Geoffrey of Monmouth, De gestis Britonum, trans. Thorpe, p. 52); "the jealous and craven" (Geoffrey of Monmouth, De gestis Britonum, trans. Faletra, p. 42).

5 Virgil, Eclogues i.1-10, ed. R.A.B. Mynors, P. Virgili Maronis Opera, Oxford, 1969, my translation; the relevant phrases are italicized: "Meliboeus: 'Tityre, tu patulae recubans sub tegmine fagi / silvestrem tenui Musam meditaris auena; / nos patriae fines et dulcia linquimus arua. / nos patriam fugimus; tu, Tityre, lentus in umbra / formosam resonare doces Amaryllida silvas.' Tityrus: 'O Meliboee, deus nobis haec otia fecit. / namque erit ille mihi semper deus, illius aram / saepe tener nostris ab ovilibus imbuet agnus. / ille meas errare boues, ut cernis, et ipsum / ludere quae uellem calamo permisit agresti." 
While the reference has been noted, its significance has not been recognized even though it offers an immediate reason for thinking afresh about how Geoffrey was using source material which was probably part of his staple education. ${ }^{6}$ It is easy to spot such allusions, but far harder to gauge their import for Geoffrey's audience.

Eclogue I has the form of a dialogue between two standard characters of pastoral, Meliboeus and Tityrus. The former begins with a contrast: while he is leaving his lands (linquimus arua / nos patriam fugimus, "we are leaving the lands of our country and its pleasant fields"), Tityrus reclines under a shady tree practicing tunes on his pipes. Tityrus replies that a god (deus) has brought him leisure (otia); he does not have to leave his land and so can relax and play his rustic pipes (calamo agresti). The historical context of the poem is well known and would have been familiar to Geoffrey: ${ }^{7}$ the poem refers to Octavian's annexation in the late 4OS BC of land in Transpadana (the area of northern Italy north of the Po, near Cremona and Virgil's home, Mantua) to pay off the veterans of the campaigns against Pompey. Despite its pastoral tone, this is a highly political poem about loss of homeland, exile, and finding new lands on the edge of the known world; as such, it encapsulates the themes played out in the $D G B$. The deus (l. 6) is of course Octavian (Augustus-to-be) to whom Virgil successfully appealed through his powerful friends to be allowed to keep his patria. Just as Tityrus can relax under a tree thanks to Octavian, so can Geoffrey under the protection of Robert and Waleran. But just as they are depicted as displaying the generosity of an Octavian, so is Tityrus at this point to be equated with Virgil and by implication with Geoffrey.

But Eclogue I is not to be set aside just yet. In the closing stanzas Tityrus offers a series of adynata "impossibilities" (of the pigs-will-fly type):

6 The link with Eclogues I is noted in Geoffrey of Monmouth, De gestis Britonum, ed. Griscom, pp. 49-50 where it is suggested that Geoffrey "modelled his new line on Virgil" (p. 50); the suggestion here is that he is simply making the allusion already present in the main part of the Preface more explicit. On Geoffrey's schooling, see below, pp. 82 and 101.

7 The circumstances of Virgil retaining his land was a standard part of all the antique and medieval lives of Virgil, and from there seem to have been absorbed into Virgilian commentaries; see Vitae Virgilianae Antiquae, ed. G. Brugnoli and F. Stok, Rome, 1997; J.M. Ziolkowski \& M.C.J. Putnam, The Virgilian Tradition. The First Fifteen Hundred Years, New Haven, 2008, pp. $179-403$. 
... sooner each shall wander in exile far from their lands

and sooner shall the Parthian drink from the Saône or the German from the Tigris

than shall his (sc. Octavian's) gaze slip from my mind. ${ }^{8}$

In his safety and self-assurance Tityrus can blithely assert that peoples will not have to travel vast distances across the world: the Parthians will not come from the east all the way to Gaul to drink the waters of the Arar (Saône), nor will the Germans travel as far east as the Tigris. But Meliboeus's response is more sanguine, "it is alright for you but ...":

But we shall go from here, some to the thirsty Africans, others to Scythia, and to Crete's swift Oaxes, and to those who are completely cut off from the world, the Britons. ${ }^{9}$

In fact, he says, people will go into exile and, what is more, they will even go to the ends of the earth, even as far as Britain.

Geoffrey's $D G B$ continues a narrative begun in Dares Phrygius's The Fall of Troy (De excidio Troiae), a text perhaps of the 5 th century AD purporting to be translated from Greek, which relates the whole of the fall of Troy in a single narrative. It ends at the moment when Aeneas abandons Troy, and this is where Geoffrey takes up the story. This is signposted by Geoffrey's allusion to Dares' title in the first line of Book I: "After the Trojan war, Aeneas, fleeing the devastation (excidium) of the city ..."10 Aeneas is like Meliboeus at this point, but not like Tityrus who is allowed to stay; just as the descendants of Meliboeus might end up in Africa or Scythia or even Britain, so the descendants of Aeneas and the Trojans end up scattered across the world. The $D G B$ then shares a Virgilian narrative whereby the Trojans become Romans and Italians, but it is a narrative which then branches off onto another tale of exile, finally bringing Brutus and his line to Britain. But it also constantly harks back to Rome - and, moreover, Romans (and those genetically related to them) seem unable to leave Britain

8 Virgil, Eclogues i.61-63, ed. Mynors, my translation: “... ante pererratis amborum finibus exul / aut Ararim Parthus bibet aut Germanus Tigrim / quam nostro illius labatur pectore uultus."

9 Virgil, Eclogues i.64-65, ed. Mynors, my translation: "At nos hinc alii sitientis ibimus Afros, / pars Scythiam et rapidum Cretae veniemus Oaxen / et penitus toto divisos orbe Britannos." 
alone. ${ }^{11}$ In other words, the link between Rome and Britain is never broken but simply re-aligned and re-shaped.

Another theme which Eclogue I opens up is that of civil war; the context of the poem is the aftermath of the destructive bellum ciuile which tore the Roman empire apart. It can be no accident that one of the few Roman authors that Geoffrey mentions by name in the $D G B$ is Lucan, but in addition, as has often been noted, Geoffrey's work is permeated with allusions to the language and imagery of Lucan's Civil War - again hardly surprising in a work preoccupied with that most destructive of activity, "war ... worse than civil". 12

This illustrates a point to which we shall return, namely that Geoffrey's use of such sources is often allusive, potentially elusive, and sometimes illusory; the apparently pastoral image of Geoffrey settled under his tree pondering his great work was not what Geoffrey intended (or at least not all that he intended), and the allusion to Eclogue I is made to work harder than might be apparent. It is more explicit in the extended prologue (with the dedication to Waleran), but for those of Geoffrey's audience with the learning to notice, it is present in the original prologue too: agresti tamen stilo propriisque calamis contentus, "content with my rustic style, reliant on my own reed pipe". ${ }^{13}$ The allusiveness of the reference in the $D G B$ recalls Conte's observations (made in relation to the use of allusion in Latin verse) that "a single word in the new poem will often be enough to condense a whole poetic situation and to revive its mood"; ${ }^{14}$ here, for those who can recognize it, the words agresti tamen stilo propriisque calamis, I would suggest, both condense and revive the mood of Eclogue I, and bring us immediately into a world of civil war, exile, and migration. Another point well made by Conte is also relevant here and that is what he calls the "epigraphic technique", the use of a quotation of, or allusion to, one poem at the beginning of another poem

11 For an impression of the presence of Rome and the Romans in the $D G B$, one need simply look at the Index in $D G B$, p. 303, s.vv. Roma, Romani, Romanus; cf. in particular $D G B$, iiii.54-72, but also episodes such as Arthur's abortive attempt to conquer Rome ( $D G B$, ix.158-x.176).

12 Lucan, The Civil War i.1, trans. J.D. Duff, Lucan. The Civil War, Cambridge, MA, 1928, p. 3: "bella ... plus quam civilia" (based on A.E. Housman's edition of the text, M. Annaei Lucani Belli civilis libri decem, Oxford, 1950). Geoffrey's reference to Lucan is in the context of Caesar's invasions of Britain where a speech of Pompey is quoted in which he disparages Caesar.

$13 D G B$, Prologus 2.13-14.

14 G.B. Conte, The Rhetoric of Imitation: Genre and Poetic Memory in Virgil and Other Latin Poets, Ithaca, 1986, p. 35 . 
whose development includes that initial poetic retrieval but subordinates it to its own purposes. What is recalled is extraneous to the new poem but it is irrevocably embedded in the other poetic situation. But the previous poetic context necessarily carries over into the new. ${ }^{15}$

Just like Geoffrey's use of Dares' title (De excidio Troiae) in the opening line of his main narrative (excidium urbis), the signposting of Eclogue I in the Preface, however oblique, allows the context and thus the thematic potential of those previous works to "carry over" into his own work. In the preface of Geoffrey's work, then, what seems on the surface to be a pastoral trope is actually highly political. We might also think of that other great poem of the countryside, the Georgics, which arguably is again a political poem pretending to be something else. In the light of our discussion of Eclogue I, when we turn to the next chapter of Geoffrey's work, "Descriptio Insulae" ( $D G B$, i.5), it becomes much easier to recognize that this might not just be a rehearsal of the standard topos of the geographical survey and the locus amoenus which we find as a preface to a range of ancient and early medieval writers, such as Tacitus, Bede, and Gildas, but rather, in terms of structure and content, a passage carefully modelled on Virgil's "praise of Italy" (laus Italiae) in the second book of the Georgics. ${ }^{16}$ But for a quirk of fate, Brutus and his people might have been Romans thriving and farming in Italy; instead Geoffrey seems to be offering them a location ideally suited to them and destined to be their homeland.

However, before we go thinking that the $D G B$ is an exercise in classical source-spotting, it is also worth noting that, when Brutus and his men eventually reach Britain, it is described as the "promised isle" (promissa insula). ${ }^{17}$ Viewed from that perspective, the biblical resonances cannot be ignored; after all, the whole of Book I is a narrative of exile, war, and seemingly endless migration. ${ }^{18}$ By chapter 20 , Britain has indeed become the promised (is)land.

While the Virgilian allusions in the prologue of the $D G B$ may have to be teased out, a classical allusion seems to have been handed to us on a plate

\footnotetext{
15 Conte, Rhetoric of Imitation, p. 25.

16 Virgil, Georgics ii.136-76, ed. R.A.B. Mynors, P. Virgili Maronis Opera, Oxford, 1969; see also Faral, $L L A$, vol. 2, p. 69 .

$17 \quad D G B$, i.2O.451-52.

18 For further discussion, see Barry Lewis's contribution to this volume, pp. 40o-1. The concept of the "promised land", which presumably lies behind promissa insula, is of course biblical, but the phrase does not occur until later patristic sources. What patristic sources Geoffrey was familiar with is an interesting question which is beyond the remit of this chapter; it is not impossible that he made the same inference from passages such as Genesis 15:18-21 as other writers have done.
} 
in the otherwise conventional opening to the $V M .^{19}$ Addressing Robert de Chesney, bishop of Lincoln, Geoffrey invokes the Muses, but at the same time claims he is not up to the task:

Indeed, it might well have been yourself whom I would wish to embrace in a

[noble poem.

But I am not the man for it: no, not even if Orpheus and Camerinus and Macer and Marius and Rabirius of the great voice were all to sing through my mouth and the Muses were my accompanists. $^{20}$

The Muses and Orpheus are standard reference points, but it is noted by Parry and Clarke that the poets Camerinus, Macer, Marius, and Rabirius are drawn from Ovid, Epistulae ex Ponto. ${ }^{21}$ Clarke suggests that Geoffrey could have drawn on a "stock list" of poets but this seems unlikely since magnique Rabirius oris, "and Rabirius of the great voice", is a direct quotation from Ovid. ${ }^{22}$ However, as we have seen, it pays to take heed of Geoffrey's sources. Ovid's poem is the final poem in his series of four books, Epistulae ex Ponto, composed in Tomis, his place of exile on the Black Sea. It is a curious poem which has not attracted very much critical attention. ${ }^{23}$ Essentially Ovid provides a list of contemporary and living poets who he supposes are still composing and thriving in the Rome from which he has been exiled, and it could be read as a complaint about how they are successful while he moulders. But by the end of the poem his stance seems to have shifted to being more concerned about his legacy: "my muse had a famous name and she was read among such men". ${ }^{24}$ That is, he was a poets' poet. The poem ends with a plea that his "body" (sc. of poetry) should

$19 V M$, ll. 1-18.

$20 \quad V M$, ll. 13-16: "Ergo te cuperem complecti carmine digno / sed non sufficio, licet Orpheus et Camerinus / et Macer et Marius magnique Rabirius oris / ore meo canerent Musis comitantibus omnes."

21 J.J. Parry, The Vita Merlini (University of Illinois Studies in Language and Literature, 10.3), Urbana, IL, 1925, pp. 20 and 119; VM, pp. 11 and 137; see Ovid, Epistulae ex Ponto iv.16.56, 19, and 24, ed. S.G. Owen, P. Ovidi Nasonis Tristium Libri Quinque Ibis Ex Ponto Libri Quattuor Halieutica Fragmenta, Oxford, 1915.

$22 V M$, pp. 11 and 137. It is possible that the poet named as Marius is an error for Marsus who is named in the same line as Macer and Rabirius.

23 The best discussion is C. Lehmann, "The End of Augustan Literature: Ovid's Epistulae ex Ponto 4", unpublished PhD thesis, University of Southern California, 2018, esp. pp. 274-341.

24 Ovid, Epistulae ex Ponto iv.16. 45-46, ed. Owen: "claro mea nomine Musa / atque inter tantos quae legeretur erat." 
not be cut up or burnt. Again there seems to be a point to this. It is tempting to read Ovid's poem as having a ring of finality about it, and after all the $V M$ is Geoffrey's final work, but we cannot know that Geoffrey intended it to be that. More significant, I suggest, is the link between Ovid's exile and Merlin's intermittent exiles (and the stress and suffering this caused to all concerned) on the one hand and the general anxiety about the nature of poetical and prophetic composition in exile. While this is less easy to pin down and must remain a suggestion, the choice of poets in this list was intended to lead the well-educated reader elsewhere, and that might have been toward reflections on the nature and consequences of exile.

\section{$2 \quad$ Previous Work}

In what follows, the classical and biblical elements in Geoffrey's work are considered side-by-side. As will emerge, it is often difficult to disentangle the two, and it is not clear that it would be helpful to do so. But even if we keep them entangled, there are methodological difficulties of several kinds. Recent discussion of Geoffrey's sources has largely focused on his proximate medieval sources, such as Historia Brittonum, Gildas's The Ruin of Britain, and Bede's Ecclesiastical History. ${ }^{25}$ But difficulties can arise where Geoffrey is using, for example, a narrative frame from Historia Brittonum but then filling it out with allusions from elsewhere. ${ }^{26}$ On the other hand, Geoffrey's use of classical and biblical sources is largely nowadays taken for granted and little further thought has been devoted to it. The earliest studies, both dissertations emanating from Halle, Tausendfreund (on Virgil) and Feuerherd (on allusions to the Old Testament) remain useful both factually and methodologically. ${ }^{27}$ This work implicitly lies behind all later work and it is important to realize how

$25 D G B$, pp. lvii-lix; see also Faral, $L L A$, vol. 2, passim; Tatlock, $L H B$, passim; S. Piggott, "The Sources of Geoffrey of Monmouth: I. The 'Pre-Roman' King-List”, Antiquity 15 (1941), 269-86; id., "The sources of Geoffrey of Monmouth: II. The Stonehenge story", Antiquity 15 (1941), 305-19; D.C. Fowler, "Some Biblical Influences on Geoffrey of Monmouth's Historiography", Traditio 14 (1958), 378-85; E. Pace, "Geoffrey of Monmouth's Sources for the Cador and Camblan Narratives", Arthuriana 24 (2014), 45-78; and especially N. Wright, "Geoffrey of Monmouth and Bede", $A L 6$ (1986), 27-59; id., "Geoffrey of Monmouth and Gildas", $A L 2$ (1982), 1-40; id., "Geoffrey of Monmouth and Gildas Revisited", $A L 5$ (1985), $155^{-63 .}$

26 An example of this is discussed below, pp. 87-89.

27 H. Tausendfreund, Vergil und Gottfried von Monmouth, Halle, 1913; P.O. Feuerherd, Geoffrey of Monmouth und das Alte Testament mit berücksichtigung der Historia Britonum des Nennius, Halle, 1915 . 
much of the later methodology can be traced back to these works. A particularly helpful illustration of this is Feuerherd's recognition of the notion of "reversal" (Umkehrung or Verkehrung); ${ }^{28}$ while Geoffrey may at times reverse the direction of the biblical allusion, the Old Testament source may still be the source with which Geoffrey was working; a simple example, discussed further below, relates to the giants: while in the Old Testament giants invaded Israel, in Geoffrey Brutus and his men come to Britain, a land inhabited by giants. ${ }^{29}$ It is clear, however, through the onomastic links that we are to see this as one of Geoffrey's sources despite the "reversal" in the direction of movement. Since then, Faral's notes to his 1929 discussion of Geoffrey's narrative are full of helpful, and mainly correct, identifications and references. ${ }^{30}$ Hammer added more specific references in a 1947 article, and the apparatus to his edition of the First Variant Version identified numerous passages, although he failed to distinguish what was unique to the First Variant and what was in the vulgate version. ${ }^{31}$ Most recently, Neil Wright has identified most of the classical and biblical references in his edition of the First Variant Version. ${ }^{32}$ Much of this work, however, useful though it has been, has tended to concentrate on quotation-spotting, without exploring how Geoffrey might have absorbed and re-processed such narratives and themes. But even if specific allusion, or even quotations, can be identified, we should be asking how this helps us understand what Geoffrey was doing and how his audiences reacted to these allusions (if indeed they ever spotted them). It is easy to take such work for granted and to assume that such traditional analysis has already been done. But it still remains for us to consider the implications of what can be argued to be a deep and wide-ranging engagement with the classical and biblical knowledge at Geoffrey's disposal.

It is interesting, too, to ask why one should need to argue in these terms for a closer and more engaged reading of Geoffrey. There may be several reasons, which in part have to do with the way we (and our students) read Geoffrey and his sources. There is, for example, a tendency to focus on the Arthurian sections

28 For examples, see Feuerherd, Geoffrey of Monmouth, pp. 30, 34, and 38.

29 Feuerherd, Geoffrey of Monmouth, p. 34; see also below, pp. 94-98.

$30 \quad$ Faral, $L L A$, vol. 2.

31 J. Hammer, "Geoffrey of Monmouth's Use of the Bible in the Historia Regum Britanniae", Bulletin of the John Rylands Library 30 (1947), 293-311; Geoffrey of Monmouth, De gestis Britonum, ed. id., Geoffrey of Monmouth. Historia regum Britanniae. A variant version edited from manuscripts, Cambridge, MA, 1951, passim. The former contains much that is debatable. One of the difficulties is that it is much easier to spot poetic diction embedded in prose, and so easier to identify classical allusions (many of which derive from classical verse), than it is to identify allusions to the prose of the Old Testament.

32 First Variant Version, ed. Wright, pp. xxiii-xxvi (and especially n. 30 (Bible), nn. 31-37 (classical)). 
of the work with less attention paid to the earlier books which are in fact much more indebted to classical and biblical modes of narrative. Furthermore, the same selectivity also applies to Geoffrey's sources: the Bible is now less well known, and the historical books of the Old Testament even less so. Likewise even the Aeneid tends to be read selectively, with some books more read than others. Books III and IX, which are highly important for our purposes, tend be among the least read books. That said, to judge from the density of glossing on medieval manuscripts of the Aeneid, medieval readers were not entirely virtuous in this regard, either. Similarly, among other classical sources drawn upon by Geoffrey, Lucan and Statius are nowadays relatively under-read.

The questions, then, which the following discussion seeks to explore center on how an appreciation and understanding of Geoffrey's sources help us to understand the $D G B$ : what did a particular verbal or episodic link with the Bible or a classical text mean to his audience? Additionally, we might return to our discussion of Eclogue I where we noted that the reference to the Eclogue in the shorter prologue was much briefer and more allusive than in the extended version containing the dedication to Waleran. It is not that the reference is indecipherable, but just that Geoffrey requires more work from his audience for them to derive full value from it. Interesting in this context is Wright's observation that one of the features which distinguishes the First Variant from the vulgate is that it contains much more explicit quotation from both classical and biblical sources. ${ }^{33}$ Turned around the other way, this example simply highlights how little direct quotation there is in the vulgate version, which begs the question, why does Geoffrey make it so difficult for us (and perhaps also for his medieval audience) to read his allusions? Was the introduction (by someone else) of more obvious quotations in the First Variant (probably within a few years of the vulgate) a silent acknowledgement that Geoffrey had made life overly difficult for his audience ${ }^{34}$

But we can begin with a more open-ended question: apart from a general expectation that he would be quoting from, and modeling his work on, biblical and classical sources, why should we think he would be? Or perhaps we might ask the question the other way round: why would we not think he would be quoting in this way? There is a broad answer which might allow us to make a little progress. In Geoffrey's view, Britons and the history of Britain form a strand of "universal history": they trace their ancestry back to Troy and beyond (like the Romans) and were a race in exile (like the Jews); Feuerherd noted that

33 First Variant Version, ed. Wright, pp. xxiii-xxvi.

34 On the authorship and date of the First Variant, see First Variant Version, ed. Wright, pp. xi-lxxviii (especially pp. lxx-lxxv). 
"Das ganze Werk macht den Eindruck, als habe es Galfred in Parallele zu der Geschichte des Judenvolkes geschrieben." ${ }^{35}$ One way of embedding Britain and the Britons in this broader historical narrative was to weave into their story the topoi and cross-references which hold all of those earlier narratives together: the rise and fall of kings, the movements of peoples, themes of treachery and deceit, patricides, fratricides, and civil wars. In that respect it might be argued that it does not really matter that a particular episode is based on a narrative attested in the Old Testament or Virgil or Lucan; it was all part of that same heroic and bloody world back into which the Britons' ancestry was to be traced and from which they had emerged.

\section{A Digression into North Wales}

This is a world which audiences of the mid-12th century would have been familiar. We might gain a firmer grasp on the expectations of a 12th-century audience by stepping back briefly from Geoffrey and looking at a text probably composed with a few years of the $D G B$ and whose author almost certainly knew it and drew upon it. Examining this text, which has never before been brought into conjunction with Geoffrey, allows us to avoid getting tangled up in the intertextual problems we encounter comparing Geoffrey's work with that of William of Malmesbury or Henry of Huntingdon, and to get a sense of what an audience might expect from such narratives. ${ }^{36}$ In 1137 , more or less when Geoffrey was letting the $D G B$ loose on the world, Gruffudd ap Cynan, king of Gwynedd, died; within a decade or so of his death, his biography, the Life of Gruffudd ap Cynan, was composed, the first and only biography of a medieval Welsh king. The author was probably a cleric, perhaps at least trained at St Davids (if not from there). He was familiar with the standard modes of biography, but also had the Latinity of the Old Testament embedded in his head. The Life of Gruffudd ap Cynan offers us a way of thinking about Geoffrey's modes of

35 Feuerherd, Geoffrey of Monmouth, p. 13: "the whole work creates the impression that Geoffrey wrote it in parallel to the history of the Jewish people"; we might compare the arrival of Brutus and his men in Britain toward the end of Book I $(D G B$, i.20.451-52) where Britain is described as the promissa insula, "promised isle".

36 On 12th-century history writing generally, see the discussions by A. Gransden, Historical Writing in England, c.550-c.1307, London, 1974, pp. 105-317; J. Gillingham, "The Context and Purposes of Geoffrey of Monmouth's History of the Kings of Britain", Anglo-Norman Studies 13 (1990), 99-118 (repr. in id. (ed.), The English in the Twelfth Century: Imperialism, National Identity and Political Values, Woodbridge, 200o, 19-39). 
reference and his weaving together of classical and biblical allusions, ${ }^{37}$ for we can observe what another biblically trained cleric from western Britain might do. Gruffudd's ancestry (and therefore his claim to the kingship of Gwynedd) was by no means clear-cut, and so the Life is structured to present someone who claimed to be royal in all branches of his kindred. For our purposes, the fact that on his father's side the biographer uses genealogical information derived from Geoffrey is less significant than that the earlier stages unite Trojans with early Old Testament figures, and thence back to Adam and God. ${ }^{38}$ The author of the Life was well-versed in Old Testament royal narratives: when in the mid-1ogos William Rufus decided to campaign in Gwynedd, his aims are summarized as follows: "... and (he) led into Gwynedd various squadrons of cavalry and infantry with which he planned to destroy and $<>$ exterminate the natives so that he might not leave even a dog pissing against a wall". ${ }^{39}$ The last phrase is strikingly Old Testament but with a literary twist; ${ }^{40}$ in Kings and Samuel, the term is used to describe the destruction of all males, but here not even the male dogs are left alive to cock their legs against any walls that might have been left standing. The next sentence takes the conceit even further: all the trees were cut down so that there was not even shade to succor the people of Gwynedd: "He also embarked upon a scheme of cutting down and destroying the forests and groves so that not even, as it were, a shadow might be left by which the weaker might protect themselves."41 Likewise, Norman kings are

37 See the Life of Gruffudd ap Cynan, ed. P. Russell, Vita Griffini Filii Conani. The Medieval Latin Life of Gruffudd ap Cynan, Cardiff, 2005; the text was translated into Welsh perhaps in the early decades of the 13th century (for which see Historia Gruffud vab Kenan, ed. D.S. Evans, Historia Gruffud vab Kenan, gyda rhagymadrodd a nodiadau gan D. Simon Evans [Historia Gruffudd ap Cynan, with introduction and notes by D. Simon Evans], Cardiff, 1977). This text had been known previously only from this Welsh version (though that was always thought to be a translation of a Latin text), but some twenty years ago the Latin text was discovered and reconstructed from a later manuscript version.

38 For discussion of his genealogy, see D. Thornton, "The Genealogy of Gruffud ap Cynan", in K.L. Maund (ed.), Gruffud ap Cynan. A Collaborative Biography, Woodbridge, 1996, pp. 79-108, at pp. 82-87; note that Thornton's discussion is based on the Welsh translation as the Latin text had not been discovered yet.

39 Life of Gruffudd §25/1, ed. Russell, pp. 78-79: "et in Venedotiam equitum peditumque varias turmas duxit, quibus incolas omnes funditus destruere et $<>$ pessundare proposuit, ut ne canem mingentem ad parietem relinqueret" (reference is by section and sentence number; < > indicates a gap caused by damage to the Latin manuscript which can sometimes be filled by reference to later copies).

40 For discussion, see P. Russell, Vita Griffini Filii Conani. The Medieval Latin Life of Gruffudd ap Cynan, Cardiff, 2005, pp. 25-26, 48, and 155 .

41 Life of Gruffudd §25/1, ed. Russell, pp. 78-79: "Aggressus est sylvas ac lucos scindere et evertere, ut ne vel umbra quidem, qua se imbecilliores tutarentur, superesset." 
described as slaughtering the people of Gwynedd in ore gladii, "at sword-point" (lit. "at the mouth of a sword"): "so that he might at last root out the realm of Gruffudd and destroy his subjects at sword-point (as it were), slaughter them, and completely wipe them out". 42 The use of ut dicam here is the equivalent of putting speech-marks around the phrase and is intended to show that this is a quotation of a common Old Testament phrase used throughout the historical books. ${ }^{43}$ However, the most striking amalgam of classical and biblical references is presented when the author digresses on the treachery by which Gruffudd was captured and imprisoned by the Normans:

No-one should be surprised at the changes in human fortunes that sometimes it is necessary to win and sometimes to flee: indeed usually the cause is treachery. For in this way the unfaithful people of Israel delivered Judas Macabaeus, their king and leader, into the hands of Demetrius, the king; Judas, however, this warrior of God, like a giant or a lion avenged himself on both. Julius Caesar who had subjugated the whole world by continuous warfare was assassinated by treachery and daggers by the senators of Rome on the Capitolium itself. Even Arthur, the outstandingly noble king of the kings of the whole of Britain, worthy of undying fame, waged twelve wars against the Saxons and the Picts. In the first of these he had been totally routed by treachery in the country of Llwyd Coed, which is also called Llwyn Llwyd. But in the remaining battles he took worthy vengeance against the Saxons $\langle\ldots\rangle$, the oppressors of his own subjects, and they could not resist even as an old man. ${ }^{44}$

Life of Gruffudd \$32/7, ed. Russell, pp. 86-87: "ut iam tandem Griffini principatum funditus eradicaret subditosque eius in ore (ut dicam) gladii perderet, mactaret, et funditus perimeret". For the biblical parallels to this phrase, see Life of Gruffudd, ed. Russell, p. 164. Life of Gruffudd, ed. Russell, p. 164.

44 Life of Gruffudd §14/13-18, ed. Russell, pp. 64-65: "Nemo miretur has humanarum rerum vicissitudines, ut interdum vincere, interdum fugere sit necesse: proditio siquidem cum primis causa est. Sic enim in manus Demetrii regis infidelis populus Israeliticus Iudam Maccabeum regem ac principem suum tradiderunt: verum Bellator hic Dei, ut gygas vel leo seipsum ultus est in utrosque. Iulius Caesar qui continuis bellis orbem terrarum sibi subiugarat, a senatoribus Romanis in ipso Capitolio Romano proditione ac pugionibus confoditur. Arthurus etiam regum totius Britanniae rex praenobilis et fama nunquam intermoritura dignus duodecim bella contra Saxones ac Pictos gessit. In quorum primo fusus fugatusque erat ex proditione in civitate Llwyd Coet quae et Llwyn Llwyt dicitur. At in reliquis de Saxonibus < > subditorum suorum oppressoribus poenas dignas sumpsit, cui ne seni quidem resistere potuerunt." For discussion, see Life of Gruffudd, ed. Russell, p. 48. 
The line of argument is essentially that all great men are brought down by treachery, as this is the only way they can fall. The triad of great men with whom Gruffudd is compared unites the worlds of the Old Testament, Rome, and Britain: Judas Maccabaeus, Julius Caesar, and Arthur. The reference to the last of these is almost certainly dependent on Geoffrey, as the $D G B$ is the earliest surviving source to present a narrative of the fall of Arthur as a result of treachery. ${ }^{45}$ But the biographical details relating to the other two are imported from the Old Testament and perhaps Suetonius, respectively, although there are plenty of sources recounting the death of Caesar. A striking feature of the Life of Gruffudd ap Cynan is that it uses the career of Judas Maccabaeus as its primary template for the life of Gruffudd: the various successes, setbacks, betrayal, and eventual triumph of Gruffudd are depicted as mirroring Judas's career. The parallels are not just thematic; for example, even the language of $u t$ gygas uel leo, "like a giant or a lion", used twice in the Life of Gruffudd ap Cynan, is a quotation from I Maccabaeus 3:3-4. ${ }^{46}$

When Gruffudd's chief poet, Gellan, is killed at the battle of Aberlleiniog, the author claims he lacks the skills of a Cicero or Homer to recount the deeds of Gruffudd in the way that Gellan would have done:

With what variety of knowledge, with what splendour of eloquence should he have been, he who could narrate the famous deeds of Gruffudd and his achievements in Wales, Ireland, and the subject isles of Denmark, and among various other peoples; I freely admit that I do not have that ability, nor indeed would I be equal to such a great task even if I had the power of the eloquence of Tullius in oratory or I could defeat Homer in formal $<$ verse $>.47$

The claim reaches back into classical literature to find the parallels which he cannot match.

Although the Life of Gruffudd ap Cynan was composed in Wales, it allows us to get a sense of how a contemporary writer, with a similar background and

45 The use of the spelling "Merlinus" in Life of Gruffudd §8/1, ed. Russell, pp. 58-59, instead of a form based more closely on Welsh "Myrddin", may also have been taken over from Geoffrey.

46 Life of Gruffudd §§14/14 and 18/8, ed. Russell, pp. 64-65, 70-71.

47 Life of Gruffudd \$23/17, ed. Russell, pp. 76-77: "Quanta scientiarum varietate, quanto eloquentiae splendore perpolitum esse oporteret qui Griffini egregia facinora, res praeclare gestas in Cambria, Hibernia, insulis Daniae subiectis, aliisque diversis nationibus enarrare posset; ingenue fateor deesse mihi facultatem, immo nec tanto oneri posse esse parem, si vel soluta oratione Tullii eloquentia pollerem, vel adstricta < > Homerum vincerem." 
training as Geoffrey's, would be working; it has the added advantage of not being a text Geoffrey could have used, though it does look as if the author of the Life may have been one of the earliest users of the DGB. The combination of particular phrases, such as in parietem mingentem, "pissing against a wall", and ore gladii, "at sword-point", together with strong narrative parallels, seem to have allowed an audience to settle into a familiar world of heroic struggle, but one in which genealogical links were important and everyone was ultimately related. In some respects, the allusions of the Life of Gruffudd ap Cynan are closer to those in the First Variant Version than the vulgate, though that might reflect its slightly later date of composition, but at any rate it can reassure us that for narrative compositions of this period what we find in the $D G B$ was not out of the ordinary, even if perhaps more allusive.

\section{$4 \quad$ Some Specific Questions}

The general question posed above as to why we would expect to find classical and biblical allusions has so far been given a general answer. But there are more specific reasons as well to expect these parallels.

First, we might consider the narrative (and in some instances the manuscript) context. As noted above, the narrative of the $D G B$ is explicitly a continuation of Dares Phrygius's The Fall of Troy. But Aeneas is a marginal figure in the $D G B$, lasting for all of five lines in the standard edition (I.vi.48-52), and perhaps for very good reasons; unlike the usual version of the fall of Troy involving the wooden horse and so on, Dares depicts Aeneas as the traitor who lets the Greeks in..$^{48}$ Dares ends at that point (and so Geoffrey effectively begins) with a catastrophic act of treachery. This would not be the last treacherous act in the $D G B$, and more specifically it is difficult to believe that the depiction of Vortigern as the king who let the English into Britain does not owe something to the Aeneas of Dares. Furthermore, as Julia Crick has noted, 27 manuscripts of Geoffrey's $D G B$ (out of a current total of 224 manuscripts) are preceded by a text of Dares. ${ }^{49}$ At a later stage, in the Welsh versions of Geoffrey, Bruty Brenhinedd ("History of the Kings"), a frequent collocation of texts is Ystorya Dared (Dares), Brut y Brenhinedd (DGB), and Brut y Tywysogyon ("History of the Princes", the medieval Welsh continuation of Geoffrey in annalistic form).

48 Dares Phrygius, The Fall of Troy §XLI, ed. F. Meister, Daretis Phrygii. De excidio Troiae historia, Leipzig, 1873; while not the form of the story used by Virgil (for obvious reasons), a similar narrative is suggested in the opening of Livy's History of Rome (i.1).

Crick, $D R$, pp. 37-39. 
Manuscript context then is one way to establish the kind of thematic connections between texts which would give rise to borrowings between them.

We should also consider what little we might know about Geoffrey's education. There is much we do not know, but it is highly likely that in the late 11th and early 12th century the young Geoffrey would have been brought up at school on versions of the so-called Liber Catonianus; the contents varied somewhat over time but invariably contained the text called Disticha Catonis ("Distichs of Cato") which consisted of a series of moralizing instructions. This evidence gives us some indication of what being well read amounted to. For our purposes, one section is particularly illuminating:

If by chance you were to want to learn about the cultivation of the land, read Virgil ... If you desire to know about the Roman and Punic wars, you should seek out Lucan who spoke of warfare. If loving pleases you in any way, or by reading it pleases you learn to love, seek out Ovid. ${ }^{50}$

It may not strike us as odd that Virgil is prescribed for reading on agriculture, when the tending of the land was an inherently political activity, but we might have thought that he would have been on the reading-list for war as well. But Lucan is recommended for war and especially for Romana ... et Punica ... bella, presumably for the Punic wars and the Civil War, though there is no evidence that he wrote anything about the former; parts of his Civil War, however, are set in Africa and that may have given rise to the confusion. ${ }^{51}$ Finally there is Ovid for love. We may ask where the prose writers are to be found, but it is likely that what we have here is a reading list for an education in verse rather than all their reading. All three authors appear in some shape or form in the $D G B$; while Virgil and Lucan would not be surprising, given the subject matters and themes, the presence of Ovid is striking. But we perhaps have to recall how many passages there are where the driving force behind the action is a man's desire for a woman, e.g. Silvius and a niece of Lavinia, Uther and Igerna, Vortigern and Rowena, and so on; no doubt the image of Helen as a catalyst of

50 Distichs of Cato, ed. M. Boas, Disticha Catonis recensuit et apparatu critico instruxit Marcus Boas, Amsterdam, 1952, p. 9o: "Telluris si forte velis cognoscere cultus, Virgilium legito ... Si Romana cupis et Punica noscere bella, Lucanum quaeras, qui Martis proelia dixit. Si quid amare libet, vel discere amare legendo, Nasonem petito." On the Distichs of Cato, see also P. Russell, Reading Ovid in Medieval Wales, Columbus, 2017, pp. 218-20, 223.

51 Punicus here should be taken to refer to North Africa rather than more specifically to Carthage; a significant element of Lucan's poem is set in Africa. 
war lies behind some of this, as is the Dido and Aeneas episode, but there is certainly Ovidian passion built into the narrative as well. ${ }^{52}$

A striking example of Ovid's presence is in the $V M$ (in addition to the allusion in the prologue ${ }^{53}$ ) where a messenger to Merlin in his mountain-top hideaway seeks to soothe Merlin's complaint by singing a lament about Guendoloena, Merlin's wife, and Ganieda, his sister: "One for a brother, one for a husband weeps." ${ }^{4}$ By the reference to cum modulis cithare, "by the notes of his lute", we are reminded at once of Tityrus under his tree..$^{55}$ At one point the laments of the two women are compared to the lamentations of Dido (when abandoned by Aeneas), of Phyllis (when Demophoon never returns), and of Briseis (at potentially losing Achilles):

So once Sidonian Dido mourned, when the fleet weighed anchor and Aeneas hastened on his way.

So once poor Phyllis sighed and wept when Demophoon failed his appointed hour.

So Briseis cried, Achilles lost. ${ }^{56}$

All three figure in Ovid's Heroides, "letters which provide a female critique of male heroism through passionate protests about the men's betrayal and abandonment of their lovers". ${ }^{57}$ Clarke observes that "these examples of womanly sorrow are in fact all different from Guendoloena's case and from one another, but it does not matter." ${ }^{58}$ However, it is not clear how different they are; it rather depends of the degree of magnification with which they are scrutinized. The common denominator is the loss of a man, husband, lover, or brother:

$5^{2}$ The sources for the female characters in Geoffrey are generally understudied; for studies, which are more interested in the contemporary context, and their treatment in later reworkings of Geoffrey, cf. F. Tolhurst, Geoffrey of Monmouth and the Feminist Origins of the Arthurian Legend, New York, 2012; id., Geoffrey of Monmouth and the Translation of Female Kingship, New York, 2013 .

53 See above pp. $7^{2-74}$.

$54 V M, 11.170-97$; quotation is $V M$, l. 187: "Hec fratrem flet et illa virum."

$55 V M$, l. 166, ed. Clarke; the translation is mine, as Clarke's rendering "by strumming on the guitar" creates quite the wrong impression; cf. Parry's translation: "with cadences on the cither", Parry, The Vita Merlini, p. 41.

$56 V M$, ll. 191-95: "Non secus indoluit Sidonia Dido solutis / classibus Enee tunc cum properaret abire. / Cum non Demophoon per tempora pacta rediret / taliter ingemuit flevitque miserrima Phillis. / Briseis absentem sic deploravit Achillem."

Tolhurst, Geoffrey of Monmouth and the Feminist Origins, p. 119; see Ovid, Heroides VII, II, III respectively, ed. and trans. G. Showerman (rev. J.P. Gould), Ovid Heroides and Amores, 2nd ed., Cambridge, MA, 1977 .

$5^{8} \quad V M$, ed. Clarke, p. 138. 
Aeneas was (in Roman eyes) married to Dido before he left her in Carthage; Demophoon seems to have been married to Phyllis but never came back; Briseis's main concern is that in his sulk Achilles will not do anything about getting her back and may go off home to Greece and leave her behind, but implicit in this is the audience's knowledge that he will be killed by Hector. At this point Guendoloena and Ganieda have no sense of an outcome and so one way of reading these exempla is that they are covering all possible options.

So far we have been considering the context of the composition of the $D G B$ and have drawn attention to the importance of drawing parallels between events in Britain and in the classical and biblical worlds. In that respect, the synchronisms are of particular importance. Throughout the early books and occasionally thereafter, Geoffrey provides synchronisms between what is happening in Britain and elsewhere, typically (and, where relevant) in Troy, Greece, Rome, and the biblical world (both Old and new Testament). For example:

At that time the priest Eli was ruling in Judaea and the Ark of the Covenant had been captured by the Philistines. The sons of Hector were ruling in Troy after the descendants of Antenor were exiled. In Italy there ruled the third of the Latins, Silvius Aeneas, the son of Aeneas and the uncle of Brutus. 59

At that time King David was ruling in Judaea, Silvius Latinus was king in Italy, and Gad, Nathan and Asaph were prophesying in Israel. ${ }^{60}$

At that time Solomon began to build the Lord's temple in Jerusalem, where the queen of Sheba came to hear his wisdom, and Italy Silvius Alba was succeeded by his son Silvius Epitus. ${ }^{61}$

At that time lived the prophets Isaiah and Hosea; and Rome was founded on April 21st by the twins Romulus and Remus. ${ }^{62}$

In his reign was born Our Lord Jesus Christ, whose precious blood redeemed the human race, bound beforehand in the chains of idolatry. ${ }^{63}$

$59 D G B$, i.22.5 o6-o9: "Regnabat tunc in Iudaea Heli sacerdos et archa testamenti capta erat a Philisteis. Regnabant etiam in Troia filii Hectoris, expulsis posteris Antenoris. Regnabat in Italia Siluius Aeneas, Aeneae filius, auunculus Bruti, Latinorum tercius."

6o $D G B$, ii.27.91-92: "Et tunc Dauid rex regnabat in Iudaea et Siluius Latinus in Italia et Gad Nathan et Asaph prophetabant in Israel."

$61 \quad D G B$, ii.28.113-15: "Tunc Salomon coepit aedificare templum Domino in Ierusalem et regina Saba uenit audire sapientiam eius, et tunc Siluius Epitus patri Albae in regnum successit."

$62 D G B$, ii.32.283-85: "Tunc Ysaias et Osea prophetabant et Roma condita est .xi. kl Mai a geminis fratribus Remo et Romulo."

$63 D G B$, iiii.64.275-77: "In diebus illis natus est dominus noster Iesus Christus, cuius precioso sanguine redemptum est humanum genus, quod anteacto tempore daemonum catena obligabatur." 
At that time the apostle Peter, after founding the church of Antioch, came to Rome, became its bishop and sent the evangelist Mark to Egypt to preach the text of his gospel. ${ }^{64}$

The synchronisms occur very frequently in Book II; there are none in Book III, and only two in Book IIII, marking the birth of Christ and the establishment of Peter as bishop of Rome. At the end of Book IIII, Geoffrey states that he has left the Christian mission in Britain to Gildas and he will focus on the history of the Britons. The first of these synchronisms seems to be adapted from Historia Brittonum, and it may be that this encouraged Geoffrey to add further synchronisms to his narrative. ${ }^{65}$ It is also noteworthy that the synchronisms peter out at much the same point as does Geoffrey's interest in reign-lengths and how the kings are related. ${ }^{6}$ In other words, by this point the $D G B$ has gradually become more inward-looking and less concerned with the world beyond Britain, though, as emerges in the narrative, that world will not leave Britain alone. But the point of these synchronisms seems to be to mark narrative stages and what is happening elsewhere (and industrious readers could have collated them with copies of the various chronicles they may have had to hand). Not only, therefore, does it give the audience a sense that Britain was part of that wider world, but it created an expectation that matters in Britain might turn out in a similar way. The high frequency of such synchronisms in Book II, especially ${ }^{26-32}$, is noteworthy, and creates a sense of events elsewhere moving very quickly; but it is a period where we see the early kings of Rome (all Brutus's relatives, in fact) synchronized with Saul, David, Solomon, and the prophets. But back home, Britain is not missing out; as we shall discuss below, Ebraucus is producing offspring from numerous wives at a biblical rate; Leil is founding Carlisle, and Rud Hudibras Shaftesbury, and a local eagle is producing its own brand of prophecy (though not much to Geoffrey's liking). The allusions need not be obvious, but one only need mention the foundation of Rome by Romulus and Remus to hint both at the dominance of Rome in the coming narrative and at the fratricidal parallels which will be played out in Britain.

$64 D G B$, iiii.68.34O-43: "Eodem tempore Petrus apostolus Antiochenam ecclesiam fundauit Romamque deinde ueniens tenuit ibidem episcopatum misitque Marcum euangelistam in Aegyptum praedicare euangelium quod scripserat." There are further synchronisms at $D G B$, ii.26.68-69, ii.26.84, ii.29.122-23, ii.30.129-3o.

65 Historia Brittonum §11, ed. and trans. J. Morris, Nennius: British History and the Welsh Annals (Arthurian Period Sources, 8), London, 1980, p. 61. I am grateful to Ben Guy for making this and the following point to me.

66 Cf. Geoffrey of Monmouth, De gestis Britonum, trans. Thorpe, pp. 286-88 for list of reignlengths and synchronisms. 
When Cassibellaunus celebrates a victory over Caesar, he does so with a feast of Solomonic proportions:

Cassibellaunus, overjoyed at having triumphed for a second time, issued an edict that all the British nobles should gather with their wives in the city of Trinovantum to hold fitting ceremonies for their native gods, who had granted them victory over so mighty an emperor. They came without delay and slaughtered animals in various sacrifices. At these were offered forty thousand cows, a hundred thousand sheep, innumerable birds of different species and also a collection of thirty thousand woodland beasts of every kind. After they had completed their offerings to the gods, they refreshed themselves with the left-over food, as was the custom at sacrifices. Then they spent the rest of the night and the following day in various sports. ${ }^{67}$

Feuerherd has noted that this is derived from the account of Solomon's feast in I Kings 8:62-63, though it has also been pointed out that the combination of feast, sacrifices, and games reads more like a Virgilian celebration. ${ }^{68}$ Typically, Geoffrey uses it to set the stage for civil strife: the young men fall out, leading to a breakdown in relations between Cassibellaunus and Androgeus, who goes over to Caesar's side and invites him back into Britain with the inevitable result. As is often the case with Geoffrey, episodes early in the narrative find reflexes later in the work: this great feast at which Cassibellaunus behaves like Solomon has close parallels with Arthur's celebration at Caerleon; ${ }^{69}$ the reigns of neither ultimately turn out well.

$67 \quad D G B$, iiii.61.134-44: "Cassibellaunus autem, secundo triumphum adeptus, maximo gaudio fluctuans edictum fecit ut omnes proceres Britanniae in urbe Trinouantum cum uxoribus suis conuenirent debitasque sollempnitates patriis deis celebrarent, qui uictoriam sibi de tanto imperatore concesserant. Cumque omnes postposita mora aduenissent, diuersa sacrificia facientes occisioni pecudum indulserunt. Litauerunt ibi .xl. milia uaccarum et centum milia ouium diuersorumque generum uolatilia quae leuiter sub numero non cadebant, praeterea .xxx. milia siluestrium ferarum cuiusque generis collectarum. Mox, cum diis suos honores perfecissent, refecerunt se residuis epulis ut in sacrificiis fieri solebat. Exin quod noctis et diei restabat diuersos ludos componentes praeterierunt."

68 Feuerherd, Geoffrey of Monmouth, pp. 52-55; Faral, $L L A$, vol. 2, pp. 153-54; Tatlock, $L H B$, p. 261.

$69 \quad D G B, \mathrm{ix} .156-57$. 
So as to avoid a piecemeal approach to discussing the multiple allusions in Geoffrey's work, what follows takes the general observations made above and applies them to three case studies. At this point we shall be less interested in identifying direct quotations and more concerned with the bigger episodes and structural themes, since they are more helpful in understanding how all of this might work. The difficulty is that one is then left to fall back on a certain amount of intuition and guess-work; if we leave aside the hard proof of a quotation, what do we have to work with that produces any kind of convincing case? In the end it will come down to likelihoods; can it really be the case that Geoffrey could quote (admittedly allusively and evasively at times) from, and direct our attention to, classical authors and biblical sources and not be aware of the bigger narrative and thematic structures into which he was reaching for those briefer and more glancing allusions? The answer must surely be that he could not have been. A further issue is the tendency to think in binary terms: it is either a classical source or a biblical source? But as we have already seen, sources can easily be both working side by side or even more closely than that; these observations reflect an underlying unease as to whether we should be even separating Geoffrey's classical and biblical inheritance from his use of other materials which themselves draw upon that same inheritance.

\section{The Travels of Brutus}

It has long been known that the basic narrative and geographical framework of the $D G B$ Book I derives from Historia Brittonum §10; the short section of text printed below encapsulates the frame of Geoffrey's Book I, which takes up 462 lines in the standard printed edition: ${ }^{70}$

Aeneas founded Alba and afterwards took a wife and she bore to him a son called Silvius. He married a wife, who became pregnant, and when Aeneas was told that this daughter-in-law was pregnant, he sent word to his son Ascanius, to send a wizard to examine the wife, to discover what

70 I follow the text used in Historia Brittonum §10, ed. and trans. Morris, pp. 19 and 6o. Manuscript variants in Mommsen's edition include Bruto and Brutus (Historia Brittonum), ed. T. Mommsen, Chronica Minora saec. IV. V. VI. VII. Vol. 3 [Minor Chronicles of the 4th, 5 th, 6th, 7 th centuries, Vol. 3] (Monumenta Germaniae Historica, Auctores Antiquissimi, 13), Berlin, 1898, pp. 111-222, at p. 15o. For further discussion of Geoffrey's use of Historia Brittonum, see Ben Guy's chapter in the present volume. 
she had in her womb, whether it was male or female. The wizard examined the wife and returned, but he was killed by Ascanius because of his prophecy, for he told him that the woman had a male in her womb, who would be the child of death, for he would kill his mother and his father, and be hateful to all men. So it happened; for his mother died in his birth, and the boy was reared, and named Britto.

Much later according to the wizard's prophecy, when he was playing with others he killed his father with an arrow shot, not on purpose, but by accident. He was driven from Italy, [...] and came to the islands of the Tyrrhene Sea, and was driven from Greece, because of the killing of Turnus, whom Aeneas had killed, and arrived in Gaul, where he founded the city of Tours, which is called Turnis, and later he came to this island, which is named Britannia from his name, filled it with his race, and dwelt there. From that day Britain has been inhabited until the present day. ${ }^{71}$

The source of much of the detail used to fill out this account is Virgil's Aeneid, and in particular Books III and Ix. The former, dramatically presented as the second part of Aeneas's narrative to Dido, relates Aeneas's storm-tossed journey from Troy to Carthage by way of Thrace, Delos, Crete, and Buthrotum on the Adriatic coast of Greece to visit Helenus, the Trojan seer. The journey is littered with confusing prophecies; the Trojans are driven in different directions by the contradictory whims of Venus and Juno, each at different times capable of turning Jupiter to their will. Throughout the narrative of these early books

$71 \quad$ Historia Brittonum §10, ed. and trans. Morris, pp. 19 and 6o: "Aeneas autem Albam condidit et postea uxorem duxit et peperit ei filium nomine Silvium. Silvius autem duxit uxorem et gravida fuit et nuntiatum est Aeneae, quod nurus sua gravida esset et misit ad Ascanium filium suum, ut mitteret magum suum ad considerandam uxorem, ut exploraret quid haberet in utero, si masculum vel feminam. et magus consideravit uxorem et reversus est. propter hanc vaticinationem magus occisus est ab Ascanio, quia dixit Ascanio, quod masculum haberet in utero mulier et filius mortis erit, quia occidet patrem suum et matrem suam et erit exosus omnibus hominibus. sic evenit: in nativitate illius mulier mortua est et nutritus est filius et vocatum est nomen eius Britto. Post multum intervallum iuxta vaticinationem magi, dum ipse ludebat cum aliis, ictu sagittae occidit patrem suum non de industria, sed casu. et expulsus est ab Italia et arminilis fuit et venit ad insulas maris Tyrreni et expulsus est a Graecis causa occisionis Turni, quam Aeneas occiderat, et pervenit ad Gallos usque et ibi condidit civitatem Turonorum, quae vocatur Turnis. et postea ad istam pervenit insulam, quae a nomine suo accepit nomen, id est Brittanniam et implevit eam cum suo genere et habitavit ibi. ab illo autem die habitata est Brittannia usque in hodiernum diem." The [...] indicates a gap in the translation where Morris omitted to render et arminilis fuit, which has admittedly defied interpretation; Mommsen notes the manuscript variants, arminiis, $\operatorname{armil}(l)$ is, $\operatorname{armimil}(l) i s$, ariminis, armiger, and some possible but unlikely emendations (Historia Brittonum, ed. Mommsen, p. 152). 
of the Aeneid, we are constantly reminded of the Trojan diaspora, Helenus and Andromache carried by Pyrrhus, Antenor, the founder of Padua, and so on. ${ }^{72}$ Book IX, on the other hand, is set in Italy after they have finally landed on the banks of the Tiber only to find the site of the future Rome already occupied by a Greek king; it relates the early struggles of the Trojans to establish a bridgehead in Italy. Book I of the $D G B$ tells of the travels of Brutus after he is sent into exile after accidentally killing his father Silvius. Brutus's journey, like that of Aeneas, is winding and slow, with several abortive attempts to settle before finally reaching Britain - which of course was his onomastic destiny. Geoffrey clearly drew on these books of the Aeneid as models. The most striking episode in this respect is his encounter with the descendants of Helenus (Aeneas's host) who had been enslaved by the Greek king Pandrasus. One of the interesting features both in Virgil and Geoffrey are the narrative reversals; just as in Aeneid IX the Trojans are at times the besieged (as at Troy), but then on other occasions also the besiegers, so Brutus, as leader of the descendants of Helenus, besieges and outwits the Greeks. Rather than remain with the permanent threat of Greek retaliation, Brutus and his men decide to leave with Brutus accepting the offer of Pandrasus's daughter Innogin as his wife. After a short journey, they land at the deserted island of Leogetia, where in an abandoned temple of Diana, Brutus seeks guidance; she appears in a dream, and in a verse prophecy, directs him to an insula in occeano ... undique clausa mari, "an island in the ocean ... surrounded by the sea". ${ }^{73}$ This passage, just like the subsequent episode in Aquitania, combines elements from both Aeneid III, IX, and elsewhere. The link with Helenus is the obvious signpost that we should look to Aeneid III, but the tactics of the warfare in both episodes with Trojans combining with Greeks, and at some points behaving like them, such as the use of deceit and trickery to overcome the enemy, a prophecy delivered on an island, can all be paralleled in these books of the Aeneid. We can also track details: Brutus's growing reputation, diuulgata ... per uniuersas nationes ipsius fama, "As Brutus's fame spread throughout every land", echoes Virgil's description of the fame of the Trojans and their war, bellaque iam fama totum uolgata per orbem, "wars now spread by rumour throughout the whole world", which Aeneas only realizes when he sees the frieze on the temple of Juno in Carthage; ${ }^{74}$ Silvius's love for a niece of Lavinia, furtiuae ueneri indulgens, "indulging a secret passion", by which Brutus was conceived, is described in the same terms as

\footnotetext{
72 M. Hurley, Geoffrey of Monmouth, New York, 1994, pp. 14-18.

$73 \quad D G B$, i.16.3o6.

$74 D G B$, i.7.75-76; Virgil, Aeneid i.457, ed. R.A.B. Mynors, P. Virgili Maronis Opera, Oxford, 1969.
} 
Dido's contemplated love for Aeneas. ${ }^{75}$ Some of the most striking connections are made, as it were, in transit: as Brutus and his men sail through the western Mediterranean (though the geography is hazy to say the least), they encounter Corineus, a descendant of Antenor, who plays a crucial role in the settlement of Britain; in the Aeneid, Venus uses Antenor as an example of a Trojan who was permitted to settle elsewhere, unlike Aeneas, who was still being hounded by Juno. ${ }^{76}$ They also encounter Achaemenides in Sicily, who was abandoned by Ulysses in the escape from the cave of the Cyclops. ${ }^{77}$ All these cross-references and parallels form part of an intricate weaving together which ties Brutus and the Britons into a bigger story.

One final aspect of the Virgilian flavor is reflected in an interest in onomastics: when Brutus finally lands in Britain,

Brutus names the island Britain after himself and called his followers Britons. He wanted to be remembered for ever for giving them his name. For this reason the language of his people, previously known as Trojan or 'crooked Greek', was henceforth called British. ${ }^{78}$

Both country and language are to be named after Brutus. In this erasure of the onomastics of Troy, there is an echo of Aeneid XII.819-40 where Juno, finally acknowledging defeat, still insists, with Jupiter's grudging agreement, on the name and language of Troy being effaced. But throughout the $D G B$, just as in the Aeneid, there is an interest in the causality of onomastics: Corineus : Cornwall; Turnus (nephew of Brutus, but echoing Aeneas's rival in Italy): Turo (Tours); Troia Nova : Trinovantum; Lud: London; the sons of Brutus, Locrinus, Albanactus, Camber: Loegria, Albania, Cambria respectively, etc. Onomastic explanations of this kind were ubiquitous in Geoffrey's world (and we would not necessarily need to seek a model elsewhere) but they are particularly common in the origin-legends of the Aeneid; for example, the explanation of the

$75 D G B$, i.6.54; Virgil, Aeneid iv.171, ed. Mynors. We might also note that this is one of the many ways in which Brutus prefigures Arthur; both are presented as the product of a "furtive love".

$76 \quad D G B$, i.17.329-30; Virgil, Aeneid i.241-49, ed. Mynors.

77 On giants, see below, pp. 94-98.

$78 D G B$, i.21.459-62: "Denique Brutus de nomine suo insulam Britanniam appellat sociosque suos Britones. Volebat enim ex diriuatione nominis memoriam habere perpetuam. Vnde postmodum loquela gentis, quae prius Troiana siue curuum Graecum nuncupabatur, dicta fuit Britannica." On "crooked Greek", see Hurley, Geoffrey of Monmouth, pp. 11-12, and Ben Guy in this volume, pp. 39-40. 
name of Latium as where Saturn "lay hidden" (latuisset, Aeneid VIII.322-23); ${ }^{79}$ and the names of the noble families of Rome as derived from the eponymous heroes listed in the catalogue of Italian heroes in Aeneid VII.640-814.

\section{The Passing of Kings and Old Testament Models for "Regime Change"}

Given the geographical range and narrative context, the primary frame of reference for the $D G B$ Book I is unsurprisingly Virgilian, and no more surprising are the Old Testament models which come to the fore in Books II-III where the succession of pre-Roman kings is narrated. Old Testament kings are usually defined by their heroic stature and courage, their fertility, and their ambitious urban planning. As Feuerherd noticed, the depiction of Ebraucus, which is a composite of Saul, David, and Solomon, does this and more:80

By his twenty wives Ebraucus fathered twenty sons and thirty daughters and ruled the kingdom of Britain with great energy for sixty years. His sons were named Brutus Greenshield, Margadud, Sisillius, Regin, Morvid, Bladud, Iagon, Bodloan, Kincar, Spaden, Gaul, Dardan, Eldad, Iuor, Cangu, Hector, Kerin, Rud, Assarach, Buel; the names of his daughters were Gloigin, Innogin, Oudas, Guenlian, Gaurdid, Angarad, Guenlodee, Tangustel, Gorgon, Medlan, Methahel, Ourar, Mailure, Kambreda, Ragan, Gael, Ecub, Nest, Chein, Stadud, Gladus, Ebrein, Blangan, Aballac, Angaes, Galaes (in her day the most beautiful woman in Britain or Gaul), Edra, Anor, Stadiald and Egron. Ebraucus sent all his daughters to Italy to Silvius Alba, who had succeeded Silvius Latinus. There they wedded Trojan nobles, whom the Latin and Sabine women refused to marry. His sons, led by Assaracus, took ship to Germany, where with Silvius Alba's help they subdued the inhabitants and conquered the kingdom. ${ }^{81}$

79 J.J. O'Hara, True Names. Vergil and the Alexandrian Tradition of Etymological Wordplay, Ann Arbor, 1996, pp. 207-08. For the use of names in Roman poetry, see O'Hara, True Names, pp. 66-73 on proper names, and $115^{-242}$ for a catalogue of the etymological wordplay in the Aeneid, and the essays in J. Booth and R. Maltby (eds.), What's in a Name? The Significance of Proper Names in Classical Latin Literature, Swansea, 2006.

8o Feuerherd, Geoffrey of Monmouth, pp. 36-39. We may note too that this paragraph is wrapped around with synchronisms referring to these kings; see above, pp. 84-86.

$81 D G B$, ii.27.95-108 (the following Latin quote omits the lists of names): "[sc. Ebraucus] [g]enuit etiam .xx. filios ex uiginti coniugibus quas habebat nec non et .xxx. filias regnumque Britanniae .lx. annis fortissime tractauit. Erant autem nomina filiorum eius ...; nomina autem filiarum ..., Galaes (omnium pulcherrima quae tunc in Britannia siue in 
Furthermore, like any self-respecting Old Testament king, Ebraucus had territorial ambitions not only in Britain, where he founded York (eponymously Kaerebrauc) and Dumbarton, but most of his sons went off and conquered Germany. He also sent his daughters off to marry the Trojans in Italy quorum cubilia et Latinae et Sabinae diffugiebant, "whom the Latin and Sabine women refused to marry", thus side-stepping the tale of the rape of the Sabine women. ${ }^{82}$ But, like all sensible rulers of Britain, Ebraucus was careful to maintain links with Europe, and the effect of such European integration is, of course, that everyone who then comes back to Britain, whether the Romans or the English (and later the Bretons), is genetically related. So even when Geoffrey is in Old Testament mode, he is careful not abandon the other strands of the narrative.

Not all reigns are explored in such detail. Variation of pace is characteristic of Geoffrey's style. After the long slow narrative of King Lear, in the passage which follows, we run through six generations in as many lines, beginning with the death of Cunedagius, briefly pausing to record (but not to dwell upon) some Old Testament plagues, bloody rain and flies, before slowing for another thematically significant moment:

When Cunedagius finally died, he was succeeded by his son Rivallo, a peaceful and fortunate youth, who ruled the kingdom well. While he was king, it rained blood for three days and people died from a plague of flies. He was succeeded by his son Gurgustius; next came Sisillius, next Iago, Gurgustius's nephew, then Kinmarcus, Sisillius's son, and finally Gorbodugo. He had two sons, called Ferreux and Porrex. When their father grew old, they quarrelled about which ones of them should succeed to the throne. Porrex felt the greater desire and tried to kill his brother Ferreux by setting an ambush, but the latter discovered the plot and escaped his brother by crossing to France. Aided by the French king, Suhardus, he returned to fight his brother, In the battle Ferreux and all the troops with him were killed. Their mother, named Iudon, was greatly angered by the news of the death of one of her sons and came to hate the other, whom she had loved less. She burned with such fury over Ferreux's death that she desired to take revenge on his brother. Waiting until he was asleep, she and her serving women fell upon him and tore him to

Gallia fuerant), ... Has omnes direxit pater in Italiam ad Siluium Albam, qui post Siluium Latinum regnabat. Fuerunt ibi maritatae nobilioribus Troianis, quorum cubilia et Latinae et Sabinae diffugiebant. At filii duce Assaraco fratre duxerunt classem in Germaniam et auxilio Siluii Albae usi subiugato populo adepti sunt regnum."

$D G B$, ii.27.106. 
pieces. For a long time after that, civil strife troubled the people and the kingdom was ruled by five kings, who inflicted defeats on one another. ${ }^{83}$

One of the major themes of the $D G B$ involves brothers falling out over the kingship and the inevitable descent into civil war (civilis discordia) which follows. ${ }^{84}$ Here Ferreux and Porrex fall out in time-honored fashion. Whether we see the model for this as Cain and Abel, other Old Testament examples, Romulus and Remus, or simply Geoffrey's own experience of 12th-century Britain (where especially in Wales royal siblings were always in dispute), the message is that this is the way it was and always will be, and the consequences are never good. ${ }^{85}$ Here we also have a maternal strand to the narrative with their mother Iudon and her maid-servants conspiring to dismember Ferreux. ${ }^{86}$ The consequence is civil war, which thematically takes us back into the world of Lucan.

But all is not lost. The last episode of Book II ushers in Dunuallo Molmutius, who is depicted as a Solomonic figure, fearless in battle and wise in peace. Once he has gained control and quelled the civil strife, he sets about handing down laws to the Britons, and generally rules like Solomon. ${ }^{87}$ But there are other echoes in this episode as well: in the midst of the battle against Rudaucus and Staterius, Dunuallo dresses 600 of his men in enemy armor and succeeds

$83 \quad D G B$, ii.33.286-304: "Postremo defuncto Cunedagio successit ei Riuallo filius ipsius, iuuenis pacificus atque fortunatus, qui regnum cum diligentia gubernauit. In tempore eius tribus diebus cecidit pluuia sanguinea et muscarum affluentia homines moriebantur. Post hunc successit Gurgustius filius eius, cui Sisillius, cui Iago Gurgustii nepos, cui Kinmarcus Sisillii filius, post hunc Gorbodugo. Huic nati fuerunt duo filii, quorum unus Ferreux, alter Porrex nuncupabatur. Cum autem pater in senium uergisset, orta est contentio inter eos quis eorum in regno succederet. At Porrex, maiori cupiditate subductus, paratis insidiis Ferreucem fratrem interficere parat. Quod cum illi compertum fuisset, uitato fratre transfretauit in Gallias sed usus auxilio Suhardi regis Francorum reuersus est et cum fratre dimicauit. Pugnantibus autem illis, interfectus est Ferreux et tota multitudo quae eum comitabatur. Porro mater eorum, cui nomen erat Iudon, cum de nece filii certitudinem habuisset, ultra modum commota in odium alterius uersa est. Diligebat namque illum magis altero. Vnde tanta ira ob mortem ipsius ignescebat ut ipsum in fratrem uindicare affectaret. Nacta ergo tempus quo ille sopitus fuerat, aggreditur eum cum ancillis suis et in plurimas sectiones dilacerauit. Exin ciuilis discordia multo tempore populum afflixit et regnum quinque regibus summissum est, qui sese mutuis cladibus infestabant." On this passage, see Faral, $L L A$, vol. 2, pp. 115-17; on the (rejected) possibility that the plague of bloody rain may derive from William of Malmesbury, see Feuerherd, Geoffrey of Monmouth, pp. 44-46.

84 Feuerherd, Geoffrey of Monmouth, pp. 16, 21.

85 Tatlock, LHB, p. 383; cf. 2 Samuel 5:13-14, 1 Kings 11:1, 3 (Feuerherd, Geoffrey of Monmouth, pp. 36-39).

86 For other powerful mothers in the $D G B$, cf. iii.41 (Tonwenna), iii.47 (Marcia), vi.107 (Merlin's mother).

87 Feuerherd, Geoffrey of Monmouth, pp. 39-44. 
in turning the tide of the battle, but timens ne a suis opprimeretur, "apprehensive of being killed by his own men", he changes his armor back again. ${ }^{88}$ Tausendfreund has noted the parallel with an episode in Aeneid II.386-437 where Aeneas and his men change into enemy-armor: "dolus an uirtus quis in hoste requirat?" “'deceit or valour, who would ask in battle?" shouts Coreobus. ${ }^{89}$ In the Aeneid, however, dolus is always associated with Greeks and not with Trojans (who are course Romans-to-be); ${ }^{90}$ the wooden horse is described as a dolus; $;^{91}$ the trickery of Sinon is characterized as uersare dolos, "employing tricks";92 and the gifts of the Greek should rightly be viewed with suspicion: aut ulla putatis dona carere dolis Danaum? "or do you think that any gifts from the Greeks are free from deceit?"93 The Trojans, of course, fall for it and, as in the episode where they change arms, it all goes wrong; Trojans simply cannot do dolus. In the $D G B$ Book II.34, Dunuallo's concern is probably well-placed; as a genetic Trojan he is not well-equipped for this, and as a wise king he knows when to stop.

Giant-Killing as a Civilizing Process

In the two preceding sections we have argued that it is possible to identify a primary source for the episode, whether classical or biblical, but it is important not to rule out influences and echoes from elsewhere. Not all instances are so easy to disentangle.

When Brutus received his traveling directions from Diana in the form of a verse-prophecy on the island of Leogetia, Britain is described as:

Brutus, to the west, beyond the kingdoms of Gaul, lies an island of the ocean, surrounded by the sea, an island of the ocean, where giants once lived, but now is deserted and waiting for your people.

Sail to it ...94

$88 \quad D G B$, ii.34.320; cf. Tausendfreund, Vergil und Gottfried von Monmouth, p. 5 .

89 Virgil, Aeneid ii.39o, ed. Mynors.

90 Cf. Virgil, Aeneid ii.152, ed. Mynors: "dolis instructus et arte Pelasga", "well trained in the Greek art of deceit"; Virgil, Aeneid ii.252, ed. Mynors: "Myrmidonum dolos", "the tricks of the Greeks".

91 Virgil, Aeneid ii.264, ed. Mynors.

92 Virgil, Aeneid ii.62, ed. Mynors.

93 Virgil, Aeneid ii.43-43, ed. Mynors.

$94 D G B$, i.16.305-12: "Brute, sub occasu solis trans Gallica regna / insula in occeano est undique clausa mari; / insula in occeano est habitata gigantibus olim, / nunc deserta quidem, gentibus apta tuis. / Hanc pete ..." 
It turned out, as often is the case with prophecies in Geoffrey (and also in Virgil), that matters were not so clear-cut; on their arrival in the promissa insula, it emerges that the prophecy was premature and that some giants did still exist. However, as soon as they were cleared out into the mountains (repertos gigantes ad cauernas montium fugant, "and (sc. after) driving off to mountain caves any giants they came upon"95), the proper civilization and cultivation of Britain could begin. The expulsion of giants, apparently throwbacks to an earlier age, seems to have been regarded as a necessary preliminary to the establishment of civilization..$^{96}$ In the distribution of territory in Britain, however, Corineus, never one to step back from a fight with a giant, was allocated Cornwall, where there were more giants still on the loose than anywhere else. These giants turn up at Totnes, Brutus's landfall in Britain, to gatecrash a feast; they were all eventually killed except for their leader, who was captured so that Corineus could fight him. Predictably the giant was defeated at Corineus's hands, who hurled him off a cliff, which was then named after him. ${ }^{97}$ There is nothing overly remarkable about any of that except that the giant went by the striking name of Goemagog. For Geoffrey's audience that name would certainly have brought to mind the Old Testament names Gog and Magog, the names of a people and a place associated with hostility to the Jews: ${ }^{98}$

And I shall send a fire on Magog, and among them that dwell carelessly in the isles: and they shall know that I am the Lord. ${ }^{99}$

And when the thousand years are expired, Satan will be loosed out of his prison, and will go out to deceive the nations which are in the four quarters of the earth, Gog, and Magog, to gather them together in battle, whose number is as the sand of the sea. ${ }^{100}$

$95 \quad D G B$, i.21.456-57.

96 On the notion of giants being things of the past, see also $D G B$, viii.129-30 (the Stonehenge narrative), during which it is asked how the stones got to Ireland in the first place; the inevitable answer is that they were brought from Africa by giants ( $D G B$, viii.129.244-45). For discussion of Geoffrey's giants in a broader context, see W. Stephens, Giants in Those Days: Folklore, Ancient History, and Nationalism, Lincoln, NE, 1989, pp. 39-40; J.J. Cohen, Of Giants: Sex, Monsters, and the Middle Ages (Medieval Cultures, 17), Minneapolis, 1999, pp. 29-42; V.I. Scherb, "Assimilating Giants: the Appropriation of Gog and Magog in Medieval and Early Modern England", JMEMS 32 (2002), 59-84, at pp. 65-68.

$97 \quad D G B$, i.21.466-89.

98 Cf. Hurley, Geoffrey of Monmouth, pp. 18, 83-84, 91-92.

99 Ezechiel 39:6: "Et immittam ignem in Magog, et in his qui habitant in insulis confidenter: et scient quia ego Dominus"; we may also note that they are located in insulis.

100 Revelation 20:7-8: "Et cum consummati fuerint mille anni, solvetur Satanas de carcere suo, et exibit, et seducet gentes, quae sunt super quatuor angulos terrae, Gog, et Magog, et congregabit eos in praelium, quorum numerus est sicut arena maris." 
While Gog is not specifically described as a giant, Genesis report that giants were regarded as throwbacks, but by interbreeding had been reduced to viri famosi, "men of renown":

There were giants on the earth in those days; and also after that, when the sons of God came in unto the daughters of men, and they bore children to them, they were the mighty men of old, men of renown. ${ }^{101}$

The immediate reaction, then, of Geoffrey's audience would probably have been to interpret these giants in biblical terms, and as another feature which tied Britain to the world of the Old Testament.

But other giants were also available for comparison and to be overcome. We have seen already how aspects of the Arthurian episode in the later books of Geoffrey echo earlier narratives, for example, the "furtive" love by which Brutus was conceived, or Ebraucus's great feast. Arthur, too, had his giants to fight en route to meeting the army of Lucius Hiberius. On hearing that a giant had arrived from Spain at Mont-Saint-Michel and was terrorizing the locals, he goes off to dispatch it single-handed. ${ }^{102}$ As such, it has all the elements of the encounter between David and Goliath (I Samuel 17) and was presumably intended to call aspects of that encounter to mind. However, the general tone of the battle and, in particular, the blinding of the giant, the destruction of boats with boulders, and the devouring of captives alive, would all have suggested another hero-giant encounter: that between Ulysses and the Cyclops, Polyphemus, probably most easily accessible to Geoffrey and audience through the Aeneid. ${ }^{103}$ This is recounted to Aeneas in Sicily by Achaemenides, a survivor of Ulysses' expedition, and has already been mentioned as an example of how the new and old worlds were tied together in Virgil. ${ }^{104}$ However, while Aeneas and Ulysses, in the different layers of this story, succeed in making their escape, Arthur goes one further and kills the giant. Almost as an afterthought, Geoffrey has Arthur refer to another encounter with a giant, Ritho on Mount Aravius, who had a propensity not only for killing his opponents but also for making a cloak out of their beards.

There are, then, classical as well as biblical resonances to these encounters with giants. Two further classical giants and their opponents seem to be

101 Genesis 6:4: "gigantes autem erant super terram in diebus illis postquam enim ingressi sunt filii Dei ad filias hominum illaeque genuerunt isti sunt potentes a saeculo viri famosi."

$102 \quad D G B, \mathrm{x} .165$.

103 Virgil, Aeneid iii.599-683, ed. Mynors.

104 See above, pp. 88-91. 
relevant here as well. Aeneid VIII opens with Aeneas being given a guided tour of the site of the future Rome. As one part of that tour, Evandrus relates the story of how Hercules, on the way back from Spain with the cattle of Geryon, fought and dispatched the half-human, half-beast Cacus, who had been terrorizing the locality. ${ }^{105}$ Here again giants are depicted as throwbacks (Cacus is a son of Vulcan) and as obstacles to civilized development; their extermination is required, especially if a hero like Hercules happens to be on hand to carry it out. We may dwell briefly on Aeneid viII and the presence of Hercules in the Roman epic. Later in the book, Aeneas is shown into Evandrus's cottage, where Hercules also stayed while getting rid of Cacus. ${ }^{106}$ Aeneas is invited to sit in the cottage, and the implication is that we are to see Aeneas as a second Hercules bringing safety and civilization to the Rome-to-be. If we accept this reading, we can see a network of implications developing which would allow an alert learned reader of the $D G B$ to link Hercules with Aeneas, Aeneas with Brutus, Brutus with Arthur, Arthur with Corineus, and now finally Arthur with Hercules.

Hercules also figures in another giant-killing episode, this time in Lucan, which arguably has a closer link to Geoffrey's concerns. Book IV of Lucan's Civil War deals with the campaigns in Libya, and in this section Lucan takes the opportunity to present a range of narratives on items of local interest. One such episode involves Hercules' encounter with Antaeus and their great battle. After a long struggle (depicted as if between two oiled wrestlers), which Hercules looks likely to lose, he realizes that Antaeus, whose mother was Terra, was gaining renewed energy and strength from contact with the earth. ${ }^{107}$ So he picked up Antaeus and held him off the ground until he died: morientis in artus / non potuit nati Tellus permittere uires, "Earth could not direct strength into the limbs of her dying son." ${ }^{108}$ Again Hercules, by removing a local trouble-maker, allowed civilization to flourish. For our purposes, however, there is a significant detail in this narrative. We might wonder whether the image of Antaeus being held off the ground until he died has influenced the depiction of Goemagog lifted off the ground by Corineus before being projected off the cliff. ${ }^{109}$ As is often the case with these kinds of parallels, there are no obvious verbal parallels, simply a parallel image which might, in the minds of some of the audience, conjure up the death of Antaeus dangling from Hercules' arms.

\footnotetext{
105 Virgil, Aeneid viii.19o-275, ed. Mynors.

106 Virgil, Aeneid viii.358-69, ed. Mynors.

107 Lucan, The Civil War iv.599-66o, ed. Housman and trans. Duff.

108 Lucan, The Civil War iv.650-51, ed. Housman and trans. Duff.

109 Cf. Faral, $L L A$, vol. 2, p. 88.
} 
Again as with other suggestions of this type, it is difficult to be precise, but the treatment of giants as an obstacle to civilization in the $D G B$ is consistent with what we see both in classical and biblical sources. To what extent Geoffrey was influenced by these different episodes is impossible to gauge, but it is unlikely that his depictions are entirely independent, nor is it surprising to see him using classical and biblical allusions in the same episode. Erich Poppe has noted a similar case in his discussion of the Middle Irish Imtheachta Aeniasa ("The Wandering of Aeneas") where the main model is, of course, the Aeneid, but where at one point a Virgilian allusion gives way to a biblical allusion about swords being turned into ploughshares. ${ }^{110}$

\section{$9 \quad$ Allusion and Evasion}

A substantial industry has grown up over the years in spotting quotations in Geoffrey from classical and biblical sources. Some of the earlier works, such as those by Tausendfreund and Feuerherd (and occasionally Faral), moved beyond a phrasal analysis to consider parallels to particular episodes. ${ }^{111}$ At various points, scholars have noted, with varying degrees of frustration and puzzlement, how difficult it is to identify Geoffrey's sources. An early comment in this regard was by Feuerherd:

Auf den ersten Blick könnte es befremdend erscheinen daß der Geistliche Galfredus Monumetensis in seiner verhältnismässig umfangreichen Darstellung nicht öfter das alte Testament anführt. Doch glaube ich, daß es Absicht des Chronisten war. Er wollte es seine Leser nicht merken lassen, daß er seine Historia der Geschichte der Juden nachschrieb. ${ }^{112}$

Feuerherd's remarks were directed at Geoffrey's use of biblical sources, but could easily be rephrased to apply more generally to his use of sources. As

110 E. Poppe, "Imtheachta Aeniasa and its Place in Medieval Irish Textual History", in R. O'Connor (ed.), Classical Literature and Learning in Medieval Irish Narrative (Studies in Celtic History, 34), Woodbridge, 2014, pp. 25-39, at pp. 27-28.

111 Tausendfreund, Vergil und Gottfried von Monmouth, pp. 16-50; Feuerherd, Geoffrey of Monmouth, pp. 24-85; Faral, $L L A$, vol. 2; Tatlock, $L H B$ was more concerned with themes to the extent that his discussion and annotating of sources tended to be patchy and scattered.

112 Feuerherd, Geoffrey of Monmouth, p. 15: "At first sight it might appear odd that the cleric Geoffrey of Monmouth in his comparatively rich presentation does not often quote from the Old Testament. But I think this was the intention of the chronicler. He did not wish his readers to notice that he was modelling his work on the history of the Jews." 
noted above, Geoffrey does not make life easy for us, only emphasized by the fact that the First Variant Version tends to give its audience a slightly easier ride. ${ }^{113}$ Geoffrey's evasiveness in this regard has long been recognized. In discussing the Goemagog episode, Faral remarks that it is not that Geoffrey is attempting to conceal his sources that is interesting, but rather that it is so easy to see through him:

Mais ces emprunts, rélativement très nombreux, Geoffrey a pris grand soin de les dissimuler. Il ne se souciait pas qu'on reconnaît ses larcins ni qu'on découvrît chez lui les traces des légendes dont l'immixtion à son récit ne pouvait que compromettre la reputation d'auteur véridique à laquelle il prétendait. Aussi, tout en empruntant, a-t-il systématiquement déformé, faisant, par exemple, de l'île de Gyaros un devin Gérion ... Toutefois, ses artifices n'ont pas suffi à cacher son jeu; s'il pille, on le prend souvent sur le fait ... s'il allègue des authorités, son imposture est souvent manifeste: ... Et l'on a si vite fait de le connaître, que ses précisions affectées, ces nombres soigneusement determinés, 600 hommes ici, 2,00o hommes là, n'ont pas d'autre résultat que de rendre plus apparents ses déguisements systématiques. ${ }^{114}$

Faral returned to the same theme later in a more general way:

Sa lecture était vaste; mais il en a porté le poids avec aisance, sans jamais être l'esclave de ses auteurs, et c'est pour cette raison qu'il est souvent si délicat de determiner ses sources. Beaucoup des épisodes de son roman ont de l'analogie avec des themes historiques ou légendaires connus de nous et qu'il a sans doute connus lui-même; mais son imagination a cueilli, transformé et adapté avec tout de dexterité, que ses emprunts sont souvent difficiles à dénoncer. Quand il a transcrit littéralement tel ou tel passage pris à autrui, il semble l'avoir fait par affectation, comme

113 See above, pp. $75^{-76 .}$

114 Faral, $L L A$, vol. 2, p. 92: "But as for these relatively numerous borrowings, Geoffrey took great care to conceal them. He did not worry if anyone recognized his or if anyone caught him out mixing together parts of legends in his narrative even though it could only compromise the reputation he was claiming as a truthful author. Also, in all his borrowings, he would systematically distort them, creating, for example, a divinity Gerion out of the island of Gyaros.... All the same, his tricks were not sufficient to conceal his game; if he plunders, he is caught at it, ... if he claims authority, his bogus claim is often clear: ... And one soon gets to know that his affected precision, his carefully precise numbers, 6 oo men here, 2000 men there, only have the effect of making his systematic concealments all the more apparent." 
pour rendre manifeste qu'il n'inventait pas: ailleurs, quand il le voulait, même s'il inspirait des auteurs les plus vénérables, Virgile ou d'autres, il savait rester libre et forger lui-même son expression. ${ }^{115}$

Tatlock's discussion, on the other hand, does not engage directly with these issues; since his discussion is more thematically based, they only surface sporadically, but even then Geoffrey's propensity for evasion is noted: "as so often, Geoffrey warily paraphrases his borrowing";116 "here, as usually, Geoffrey's literary reminiscences are merely vague and disguised."117 The irritation with Geoffrey and almost a hand-wringing despair are evident in a comment toward the end of his work: "useless to guess where Geoffrey got the idea".118

The source-hunting and text-combing will no doubt go on and continue to give rise to further expressions of frustration and imputations of culpability against Geoffrey. But there is an underlying question that is never really addressed: why does Geoffrey make his audience work so hard? Now this question may be approached in a number of different ways. One is hinted at in one of Faral's comments quoted above where he observes that Geoffrey seems unbothered by the fact that one can see through his disguises even though that might compromise his claim to be writing history. The point is in part that Geoffrey's sense of writing history involves reference to earlier sources, but at the same time those sources themselves indulge in imaginative digressions and reconstructions. One particular instance of this is the use of imaginary speeches often just before battles, or, an extension of this device, the exchange of imaginary correspondence, the rhetorician's sermocinatio. ${ }^{119}$ This has been part of the historian's tool box from Herodotus and Thucydides onwards and

115 Faral, $L L A$, vol. 2, p. 398: "His reading was vast; but he carried its weight with ease, without ever being slave to his authors, and it is for that reason that it is often so tricky to establish his sources. Many episodes of his story bear an analogical relationship with the historical and legendary themes known to us, and he doubtless knew them himself; but his imagination has gathered them in, transformed and adapted them with such dexterity that his borrowings are often difficult to identify. When he has literally transcribed this or that passage from somewhere, he seems to have done so for show, as if he was making it clear that he had not made it up; elsewhere, when he wanted, even if inspired by the most venerable authors, he knew how to remain free and to craft his own expressions."

116 Tatlock, $L H B$, p. 26o, n. 14.

117 Tatlock, $L H B$, p. 342, n. 127.

118 Tatlock, $L H B$, p. 39 o.

119 See H. Lausberg, Handbook of Literary Rhetoric, trans. M.T. Bliss et al., Leiden, 1998, pp. 366-69, at p. 366: "the fabrication - serving to characterize natural (historical or invented) persons - of statements, conversations, and soliloquies or unexpressed mental reflections of the persons concerned". 
is liberally exploited by Geoffrey. The classical antecedents for such speeches would have been clear for him (his model very probably being Sallust, whom he quotes on several occasions), as also would have been the implied license to create one's own; a subtle nod toward them is offered in Hoelus's reply to Arthur's speech rejecting Lucius Hiberius's demand for tribute in which he describes Arthur's deliberatio as Tulliano liquore lita, "soaked in Cicero's honey".120 That the accumulation of speeches in the $D G B$ was seen as characteristic of Geoffrey's presentation is suggested by the fact that one distinguishing feature of the First Variant Version is the removal or reduction of some of the speeches found in the vulgate. ${ }^{121}$ If then we view Geoffrey's treatment of his classical and biblical models in the light of how he uses speeches, it may not be so surprising that a precise tracking and accounting of sources and quotations is not always possible. Furthermore, it is not clear that Geoffrey was necessarily intending a precise and identifiable references on all occasions; a glancing partial quotation (or even not textual reference at all) may have been all that was needed to direct his audience to the model (or models) he had in mind. As has been argued above, his general aim seems to have been to present the travels of Brutus and the settlement of Britain as emanating from, and forming part of, the same world as depicted in the sources with which he and his audience would have been very familiar. In sum, we may have simply to accept that Geoffrey was often being very vague.

Another approach, which may perhaps prove more satisfying, is to think about the kind of rhetorical training which Geoffrey would have received in the late 11 th and early 12 th centuries. It has generally been thought that rhetorical training went through significant changes in the 12th century, but Geoffrey's training is likely to have been more "old-school" where ideas of imitatio and aemulatio figured significantly. ${ }^{122}$ While imitatio was an important element in rhetorical training, slavish imitation was only acceptable at an elementary stage, and aemulatio was the goal: to go beyond simple imitation to create something new but still based on the respected models. ${ }^{123}$ However, that connection to the model may well be disguised and dependent on the knowledge of the audience to make the links and to appreciate the subtlety of the

\footnotetext{
$120 \quad D G B$, ix.16o.483-84.

121 First Variant Version, ed. Wright, p. xxxix (Wright's category H).

122 There is a problem of talking about rhetorical training in the late 11th century and early 12th century; while the 12th century may have been a period of renewal, most rhetorical studies are very silent on the preceding century.

123 Conte, Rhetoric of Imitation, pp. 32-39. On imitatio and aemulatio, see R. Copeland and I. Sluiter (eds.), Medieval Grammar and Rhetoric. Language Arts and Literary Theory, $A D$ 300-1475, Oxford, 2009; Lausberg, Handbook of Literary Rhetoric, pp. 483-85, 499.
} 
approach. An interesting and potentially revealing illustration of these techniques can be found in the central books of Macrobius's Saturnalia in which this highly literary discussion turns to Virgil's debt to Homer. ${ }^{124}$ The crucial point for our purposes here is the concept of the "well-disguised imitation":

... sometimes he conceals the imitation of his model so that he changes only the arrangement of the passage he has borrowed and makes it seem like something else. ${ }^{125}$

Those who know the texts well enough can see past the aliud videri, "the fact that it seems like something else", and gain added value; for those who cannot, Virgil provides entertainment and interest enough anyway. Slightly later in the same discussion, Macrobius is more explicit and suggests that part of being scrupulosus et anxius, "thorough and painstaking", was to disguise one's sources:

... for just as our poet's learning was thorough and painstaking so was it well-disguised and as it were covert to the extent that it is hard to recognize the sources for many of his borrowings. ${ }^{126}$

This strand of antique literary criticism runs more deeply; the theme of making things look other than they are, with the emphasis on ideas of dissimulation and secrecy so that the audience can take pleasure in seeing through the veil, is also found in a comment by the Elder Seneca who seems to be offering us the exception that proves the rule: in a discussion of Ovid's borrowing of Virgilian phrases, it is proposed that Ovid liked the phrases so much that he made it clear that it was a borrowing: non subripiendi causa sed palam mutuandi, hoc animo ut vellet agnosci, "not for the sake of stealing but of open borrowing,

124 For discussions of this passage, see S. Hinds, Allusion and Intertext: Dynamics of Appropriation in Roman Poetry, Cambridge, 1998, p. 25, and B. Miles, Heroic Saga and Classical Epic in Medieval Ireland, Woodbridge, 2001, pp. 143-44.

125 Macrobius, Saturnalia v.16.12, ed.J. Willis, Ambrosii Theodosii Macrobii Saturnalia, 2nd ed., Leipzig, 1970: "interdum sic auctorem suum dissimulanter imitatur, ut loci inde descripti solam dispositionem mutet et faciat velut aliud videri."

126 Macrobius, Saturnalia v.18.1, ed. Willis: “... fuit enim hic poeta ut scrupulose et anxie, ita dissimulanter et quasi clanculo doctus, ut multa transtulerit quae unde translate sint difficile sit cognita." On the sense of dissimulanter in these passages, see Hinds, Allusion and Intertext, pp. 23-24. 
with the intention of having it recognized". ${ }^{27}$ The point here, it seems to me, is that, while Ovid was pleased to be seen alluding to Virgil, he was more evasive about his allusions to other authors.

As Brent Miles puts it in a recent work on the adaptation of classical epic in medieval Ireland, "the intention was to vary the imitation enough for the source not to be obvious without the exercise of the reader's/hearer's erudition." 128 This is not just an issue for the transmission and adaptation of classical and biblical sources in medieval literature (where sometimes one also has to deal with adaptation into the vernacular). Strategies of intertextuality, the adaption of, or allusion to, the work of one classical author by another, has always attracted critical attention from the scholia on Homer and Servius's commentary on Virgil onwards. But, as Hinds has argued in his exemplary study, "[sc. This] is a relationship between author and reader which can involve indirection as much as direction, concealment as much as revelation." ${ }^{129} \mathrm{He}$ argues that in many instances it is difficult to discern the precise links amidst the "noise" of intertextual echoes, and "it will be more important to affirm the existence of a shared discourse than to classify the individual voices which make up that discourse." ${ }^{130}$ Applied to Geoffrey's use of classical and biblical sources, such an approach would encourage us first to acknowledge the existence of that discourse (and that seems clear from Geoffrey's prologue onwards) and then explore it in a range of different ways. Just as Hinds shows that the precision of an allusion can be illusory when the broader range of verbal echoes are brought to bear, ${ }^{131}$ so with Geoffrey we know so little of the chronologically intervening material that we cannot be sure whether he is alluding to a classical or biblical source directly or whether he had encountered it in a different context, or indeed whether he is doing all these things at the same time.

The nature of Virgil's debt to Homer has been characterized in a well-known metaphor, dating from the late antique period as "snatching the club from Hercules". 132 The general import of the metaphor has to do with the quality

127 Seneca the Elder, Suasoriae 3.7, ed. M. Winterbottom, The Elder Seneca, Declamations: Controversiae and Suasoriae, 2 vols., Cambridge, MA, 1974, vol. 2, pp. 544-45; see also Hinds, Allusion and Intertext, p. 23, where he takes this as a "reference" rather than as an "allusion" and as functioning as a "guarantee of the author's integrity". On the significance of subripiendi here, see below.

128 Miles, Heroic Saga and Classical Epic, p. 144.

129 Hinds, Allusion and Intertext, p. 25.

130 Hinds, Allusion and Intertext, pp. 50-51.

131 Cf. the examples discussed in Hinds, Allusion and Intertext, pp. 26-51.

132 For discussion in an Insular context and on the metaphors associated with subripere and extorquere, see A. Burnyeat, "Wrenching the club from the hand of Hercules': Classical 
and process of the reproduction of epic material. As we have argued, Geoffrey's debt to his classical and biblical sources in the $D G B$ is pervasive but multifarious: not only did he inter alia snatch a club from Hercules, but he also stole a sling from David, a shield from Aeneas, and ideas of kingship from Solomon and of civil war from Lucan. In doing so he did his best to conceal his efforts and leave his audiences to work it out for themselves.

Models for Medieval Irish compilation", in O'Connor (ed.), Classical Literature and Learning, pp. 196-207. 